\title{
PRAGMATIC COMPETENCE OF SERBIAN LEARNERS OF L2 SPANISH
}

The purpose of the present communication is to provide insights into interlanguage variation in speech act realization by examining the speech act of refusal produced by Serbian-speaking learners of L2 Spanish. Therefore, production data from Serbian learners of L2 Spanish will be collected and compared to those of a native control group as a benchmark. More precisely, the aim is to find out which semantic formulas Serbian learners of L2 Spanish employ when performing refusals in different social status situations and how this relates to the refusals produced by Spanish native speakers. To achieve the goal, a discourse completion task (DCT) will be used and the data will be classified and analysed according to Beebe, Takahashi and Uliss-Weltz's (1990) taxonomy of refusal strategies.

Keywords: pragmatic competence, speech acts, refusal, Spanish as a second/ foreign language.

\section{Introduction}

Both linguistic proficiency and pragmatic competence constitute essential aspects for second language learners (L2) to become effective language users (Le Pair 2005; Tanck 2002). While the former enables correct usage of language; the latter is indispensable for producing and understanding the language appropriately and in conformity with particular sociocultural parameters (Abed 2011; Alcón-Soler 2001; Tello Rueda 2006). In the field of second language acquisition (SLA), most research has been done on linguistic proficiency ( $c f$. Housen, Kuiken, \& Vedder 2012; Norris

\footnotetext{
* Vrije Universiteit Brussel, Faculty of Arts and Philosophy, Pleinlaan 2, 1050 Brussel; jovana.stanojevic@vub.be
} 
\& Ortega 2003). The pragmatic dimension has been studied to a lesser extent and has mainly focused on English as a target language (Halupka-Rešetar \& Knežević 2016; Taguchi 2017). According to Fernández Amaya (2008), even fairly advanced learners still have difficulties to achieve native-like pragmatic competence. Thus, the present research aims to extend the range of first and second languages in interlanguage pragmatics (ILP) by investigating more in detail the speech act of refusal produced by Serbian-speaking learners of L2 Spanish. More specifically, data from Serbian learners of L2 Spanish will be collected and compared to those of a native control group in order to find out whether Serbian learners of Spanish opt for similar speech act realization strategies as Spanish native speakers in the same refusal situations. If not, further emphasis will be on major differences between these two groups when performing refusals.

Speech acts in general, and refusals, in particular, are highly interesting to study, as part of a ritual where sociocultural factors influence its actual performance. In other words, performing speech acts can differ from one community to another, from one language to another. In addition, it is important to point out that refusals are face-threatening acts (FTAs), because saying "no" can be challenging and can mean disapproval of the interlocutor's intentions. Therefore, the speech act of refusal often requires the use of indirect strategies as well as mitigation devices to soften the possible threat and maintain a good relationship with the interlocutor. So, for non-native speakers of a language the development of pragmatic competence is important in order to avoid being considered as rude, uncultured, or even offensive (Martínez-Flor \& Usó-Juan 2011).

Finally, we share the view of Nadal Lopez (2012: 4) that Slavs in general and Serbs in particular seem to learn the Spanish language in record time and already speak fluently from the early stages. Nevertheless, we expect to find some differences in the use of certain strategies and the degree of politeness. Therefore, our hypothesis is that Serbian learners will be able to produce what they want to say, but they may lack the necessary sociocultural knowledge and pragmatic ability to express themselves in an appropriate way.

\section{Theoretical background}

\subsection{Interlanguage pragmatics and taxonomy of refusals}

The present study is situated in the field of interlanguage pragmatics (ILP),

the study of learners' comprehension and production of speech acts, and the ac- 
quisition of L2 pragmatic knowledge (Kasper \& Rose 2003; Taguchi \& Roever 2017). One of the most influential studies has been the Cross-Cultural Speech Act Realization Project (CCSARP) conducted by Blum-Kulka et al. (1989) on cross-cultural and intralingual variation in the realization of requests and apologies. According to Brown and Levinson's (1987) politeness framework, politeness strategies are employed to save face, and three variables, social power, distance and degree of imposition, are taken into account to evaluate the weight of a speech act. As such, face-threatening acts (FTAs), since they contradict listeners' expectations, usually involve long sequences of negotiation as well as many face-enhancing moves (Brown \& Levinson 1987; Eslami 2010).

With respect to the speech acts of refusal, classified as high-risk face-threatening acts, they function as negative responses to various initiating acts such as invitations, offers, requests or suggestions (Siebold \& Busch 2015). Although recognized as a major "sticking point" for many non-native speakers (Beebe et al. 1990: 56), refusals have not been as widely explored (Savić 2014: 72). The most influential taxonomy of refusal strategies is the one developed by Beebe $e t$ al. (1990). They distinguish three types of strategies used in refusals: direct strategies, indirect strategies and adjuncts (or external modifications), i.e. strategies that cannot by themselves be used to perform a refusal but contribute to refusal mitigation and can, thus, be considered as supporting moves which either precede or follow the actual refusal. Within the category of direct refusals, a distinction is made between non-performative statements such as the use of an explicit and clear "no" and performative verbs such as "I refuse". Indirect strategies include 11 subcategories such as the use of explanations (e.g. "I have to study"), statements of regret (e.g. "I'm sorry"), statements of alternative (e.g. "Why don't you ask John to help you"), promises of future acceptance (e.g. "I promise I'll send you the documents next week"), etc. Finally, adjuncts are divided into four subcategories such as statements of positive opinion (e.g. "I'd love to join you for the party, but..."), statements of empathy (e.g. "I know how difficult it is for you"), gratitude (e.g. "Thank you") and pause fillers (e.g. "well"). Furthermore, refusals can be internally modified by syntactic downgraders (e.g. subjectivizers such as "I am afraid I can't go"; modals such as "I am afraid I can't go"), lexical downgraders (e.g. the use of specific politeness markers such as "please", of specific interpersonal markers such as "But you know", hesitation devices such as "Er... sorry"; downtoners such as "Maybe I can't lend it to you"), and upgraders (e.g. adverbial intensifiers such as "I am really sorry"). 


\subsection{Previous research on refusals in ILP}

Perhaps the most influential publication on refusals in ILP has been Takahashi and Beebe's (1987) investigation on refusal strategies employed by American English speakers and Japanese EFL learners. Findings from this study showed that learners with a higher proficiency were able to soften their refusals with modal verbs, yet learners with a lower proficiency used more direct refusals such as "I can't". The data for the analysis were collected by means of a written test, a Discourse Completion Test (DCT). Robinson (1992) also compared written refusals produced by American English speakers and Japanese ESL students and concluded that the lower proficiency students were more influenced by Japanese refusal style, whereas the more proficient learners knew how to make refusals in an American context. In another study, Tanck (2002) examined written refusals performed by native English speakers and non-native English speakers, whose first languages included Polish, Russian, Serbian, Korean, Chinese, Thai and so forth. The analysis of the data revealed that non-native speakers avoided the typical native components (expression of regret, excuse and offer), which could lead into unintended offense or breakdown in communication. Finally, Allami and Naeimi (2010) investigated refusals of Persian EFL learners and American English speakers, also by means of a DCT and their findings indicated that Iranians used various formulae such as "I know that you are one of my best workers" more than the Americans to mitigate their refusals.

With regard to Spanish as a second language, the target language of the present research, Félix-Brasdefer (2004) analysed the realization of refusals by 24 American learners of Spanish, using role-play interviews and retrospective verbal reports. Role-plays are another widely used research instrument to elicit data in ILP studies. They have the advantage of including interaction in a face-to-face format with another interlocutor. Retrospective verbal reports, on the other hand, were administered in order to verify the findings of the production data. The results showed that learners with more extended length of residence in the target community made more attempts at negotiating and tended to employ lexical and syntactic mitigation strategies more frequently. In addition, a preference for solidarity was revealed, which seemed to approximate native Spanish speaker norms.

In sum, current literature on refusals have focused largely on English as a target language. Given that Spanish is the second most spoken language in the world by number of native speakers and one of the most widely studied languages, more research on L2 Spanish has to be conducted. Moreover, this study involves a par- 
ticular group of L2 Spanish learners, namely those learners whose first language, Serbian, has not been addressed extensively in research on ILP so far.

\section{Methodology of the research}

\subsection{Participants}

In the present study a total of 40 students participated: 20 Serbian learners of Spanish as a foreign language and 20 Spanish native speakers. All Serbian learners of Spanish are third-year students majoring in Spanish Language \& Hispanic Literatures at the University of Belgrade, and their level of Spanish corresponds to the B2 level. At this level, students are supposed to have a sufficient degree of fluency to interact with native speakers, they are supposed to be able to handle refusal strategies, know politeness formulas, know how to apologise or make a future promise and know how to explain the reason for a refusal. More precisely, the participants' ages range between 20 and 22 years old and the majority of students (13/20) have spent between one and four weeks in Spain, whereas seven students have never been in a Spanish-speaking country. The half of the Serbian students had already studied Spanish before the university (e.g. private schools, the Cervantes Institute, secondary school), whereas the other half had not been in contact with Spanish before their studies at university.

As for the native control group, they are all students at the University of Madrid. Only three Spanish native speakers are between 25 and 27 years old, while the rest of the group (17/20) are between 18 and 19 years old.

In sum, the basic information about the participants is given in Table 1.

Table 1. Background information about the participants

\begin{tabular}{|c|c|c|}
\hline & Serbian learners & Control group \\
\hline Number of students & 20 & 20 \\
\hline Mean age & 21.05 & 19.03 \\
\hline Proficiency level & B2 & Mother tongue \\
\hline Stay abroad & Yes (11) / No (9) & $/$ \\
\hline Knowledge of Spanish before university & Yes (10) / No (10) & $/$ \\
\hline
\end{tabular}




\subsection{Research instrument and corpus compilation}

The research data were collected through a written Discourse Completion Test (DCT), in which participants had to refuse what is proposed to them. The DCT was originally developed by Blum-Kulka (1982) and has been widely used later for data collection on speech act performance. More precisely, the DCT is a standard form in which a situation is presented, followed by a brief dialogue and the participants are asked to complete the conversation (Martínez-Flor \& Usó-Juan 2011). In other words, participants are invited to respond in a written mode everything they would answer orally. Considering this aspect, it might be possible that their written answers do not correspond to what they would actually produce under real circumstances (Golato 2003). Aware of this disadvantage we want to underline that it would be very difficult to collect data through spontaneous speech. Furthermore, in a DCT, social variables (e.g. age, gender, social power, social distance) can be easily controlled. Another advantage is that there is no need for transcriptions, which makes DCTs more feasible in terms of analysis (Chaudron 2003). This is why a written test seems to be a good option to obtain data from a larger group of participants in a relatively short period of time (Houck \& Gass 1996).

In our study, the DCT consists of six different situations, originally presented in Spanish, of which two are analysed in detail in the present study. In Table 2, a summary of these two situations is presented together with an indication of the context, the participants' role, the social status and the social distance between the interlocutors.

Table 2. Contextual information on DCT situations

\begin{tabular}{|c|c|c|c|}
\hline & $\begin{array}{c}\text { Participants' roles in DCT } \\
\text { situations }\end{array}$ & $\begin{array}{c}\text { Status variable } \\
\text { (Speaker's perspective) }\end{array}$ & $\begin{array}{c}\text { Distance } \\
\text { variable }\end{array}$ \\
\hline 1 & $\begin{array}{c}\text { The friend refuses to help } \\
\text { you with a test of English }\end{array}$ & $=$ & - \\
\hline 2 & $\begin{array}{c}\text { The grandchild refuses to } \\
\text { close the window }\end{array}$ & + & + \\
\hline
\end{tabular}

The equal sign in the Status column means that the social status of the speaker and the hearer is equal, while the plus sign in the Status column means that the speaker has a higher social status than the interlocutor. The minus sign in the 
Distance column means that the speaker and the hearer know each other, whereas the plus sign in the Distance column means that the speaker and the hearer do not know each other ( $c f$. Sasaki 1998).

\section{Data analysis}

For the data analysis the following procedure was adopted for each situation. First, the sequential organization of each illocutionary act was examined. Then, the components of each speech act were detailed in line with Beebe et al.'s (1990) taxonomy of refusals (described above in the theoretical part, section 2.1). Other aspects which were also considered were the use of internal modifications (i.e. syntactic and lexical downgraders/upgraders) such as the use of specific politeness markers, interpersonal markers, hesitation devices, downtoners, adverbial intensifiers, etc.

\subsection{Situation 1}

The first situation is presented as follows:

Your friend has a problem with a test of English. You have already passed it. He/she asks if you can help him/her with the exam. You want to help but you are very busy with your obligations.

A. Friend: Hello. I would like to ask you a favour. You know how difficult the exam is. Could you please help me?

B. You:

As for the sequential organization of the refusal strategies used in the first situation, the majority of the Serbian learners of L2 Spanish begin with an expression of regret such as "Lo siento", "Lo siento mucho" ("Sorry", "I am very sorry"). There are also some participants who start the speech act of refusal with an expression of greeting followed by an address term, e.g. "¡Hola amigo!” ("Hello, my friend!”), “iHola Nataša!” ("Hello, Natasha!”). After the statement of regret, all participants try to explain and justify the impossibility of helping their friend, e.g. "Tengo muchas cosas que hacer ahora mismo" ("I have a lot of things to do right now"), "Estoy muy ocupada, tengo muchas obligaciones" ("I'm very busy, I have many obligations"), "La semana que viene tengo muchos exámenes y tengo que estudiar demasiado" ("Next week I have a lot of exams and I have to study a 
lot"), "Tengo que estudiar mucho, aun no he aprobado mis exámenes" ("I have to study a lot, I haven't passed my exams yet"), "Tengo mis problemas y no tengo tiempo para ayudarte" ("I have my problems and I don't have time for helping you"). As we can see, their explanations remain rather vague, that is to say, they just stress the lack of time or that they have their own obligations. At the end of the refusal speech act, the majority of the learners employ the direct refusal strategy, e.g. "Me gustaría ayudarte, pero estoy muy ocupada. De verdad, no puedo ayudarte" ("I would like to help you, but I am very busy. I really can't help you"). Statements of alternatives are seldomly found in their responses. More precisely, only two participants suggest an alternative, e.g. "¿Podemos hacerlo otro día?" ("Can we do this another day?"), "Me puedes llamar por el teléfono y te explico todo" ("You can call me and I will explain everything to you").

Other elements employed by the Serbian participants are adverbial intensifiers, e.g. "Lo siento mucho" ("I am very sorry"), wishes such as "Espero que apruebes" ("I hope you will pass the exam"), "Suerte, tío" ("Good luck, man"), appealers such as "Lo entiendes, s'́ ("You understand me, don't you?"), pause fillers such as "es que" ("the thing is that"), colloquial terms of address such as "tío" ("man") and subjectivizers such as "No creo que tendré tiempo para esto" ("I don't think I'll have time for this").

On the other hand, the Spanish native speakers never start with a statement of regret but mostly with a statement of positive opinions/feeling such as "Me gustaría ayudarte..." ("I would like to help you..."), "Te ayudaría, pero..." (“I would help you, but...”). Then, like the Serbian learners, the Spanish participants also explain the reasons that prevent them from helping their friend, e.g. "Tengo que enviar un proyecto antes del lunes y todavía no lo he terminado" ("I have to submit a project before Monday and I haven't finished it yet"), "Este fin de semana tengo que hacer muchas cosas aparte de ayudar a mi madre en casa" ("This weekend I have to do many things besides helping my mother at home"), "Tengo médico esta tarde" ("I have an appointment with my doctor this afternoon"). It is necessary to underline that the control group provides more different explanations rather than just stressing the lack of time. To finish the speech act of refusal, many native speakers opt for a statement of alternative, mainly expressed syntactically by using conditional clauses, e.g. "Si quieres, te dejo mis apuntes" ("If you want, I can give you my notes"), "Si tienes algunas dudas, llámame o mándame un mensaje" ("If you have some doubts, call me or send me a message"), interrogative forms, e.g. "¿Quieres mejor quedar otro día? " ("Do you want us to meet another day?”), ¿Por qué no llamas a un professor particular?” (“Why don’t you 
call a professor?") or modal verbs, e.g. "Te puedo pasar el contacto de Betty, una profesora nativa que te podrá ayudar" ("I can give you a phone number of Betty, she is an English native speaker and she may help you").

Furthermore, in the productions of the control group we find lexically expressed negations such as "Imposible" ("Impossible"), pause fillers such as "pues" ("well"), "es que" ("the thing is that"), address terms such as "tío", "chico" ("man"), subjectivizers such as "No sé si podré" ("I don’t know if I can") and repetitions such as "¿Este fin de semana?" ("This weekend?”). According to Haverkate (1996: 48-49), the repetition of the speaker's words is a prototypical strategy in Spanish culture. In this way, the hearer announces that he or she shares the point of the interlocutor.

To sum up, the findings show that the both groups employ colloquial terms of address, e.g. "tío" ("man"), and pause fillers, e.g. "pues" ("well"), "es que" ("the thing is that"), which are used very frequently in Spanish discourse. As for the differences, it is important to indicate that the Spanish respondents do not employ statements of regret and adverbial intensifiers as often as the Serbian participants do. However, they do elicit more statements of alternative. According to Haverkate (1994) and Hickey (2005), Spaniards feel less obliged to apologise and thank, whereas statements of alternative are more representative of Spanish culture. Moreover, learners' explanations seem to be shorter and vaguer, which could be interpreted as a lack of interest and courtesy. Finally, in the learners' refusals there are no lexically expressed negations such as "Imposible" ("Impossible") nor repetitions of the interlocutor's words.

\subsection{Situation 2}

The second situation is elaborated as follows:

Your grandmother asks you to get up and close the window. You are sitting on the couch and you are very tired, so you don't feel like doing it.

A. Grandmother: Maria, daughter, close the window, it's cold here.

B. You:

The two groups of participants employ similar strategies, but the position of certain strategies seems to be somewhat different. The majority of the Serbian learners start with syntactically expressed negations such as "No puedo levantarme ahora" ("I can't get up now") or "No me apetece levantar ahora" ("I don’t 
feel like getting up right now"). Next, all the learners (20/20) explain why they cannot close the window, e.g. "Estoy muy cansada" ("I am very tired"), "Me duele la cabeza" ("I have a headache"), followed by address terms, e.g. ten participants use the term "abuela" ("grandmother"), while only four prefer the diminutive "abuelita" ("grandma"), which is extensively used in Spanish (Márquez-Reiter 2000: 137). Finally, it is worth mentioning that five learners ask the grandmother whether she can close the window. Two of them use the imperative mode but preceded or followed by the politeness marker, e.g. "Por favor, ciérrala tú" ("Please, close the window"), "Si tienes frío, ciérrala tú, por favor" ("If you are cold, (you) close the window, please"). Only one request is realized by means of an interrogative form using present modal verbs, e.g. "¿Puedes hacerlo tú?" ("Can you do it?"). Other strategies registered in the learners' corpus are statements of regret, e.g. "Lo siento" ("I am sorry"), pause fillers, e.g. "es que" ("the thing is that"), "iay!" ("oh!"), adverbial intensifiers, e.g. "Estoy muy cansada" ("I am very tired”), appealers, e.g. “¿ok?” (“OK?”) and postponements, e.g. "Voy a cerrarlo después" ("I will close it later").

Regarding the results of the native control group, they mostly start with ad-

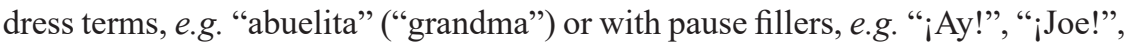
"¡Ais!” ("Oh!”) followed by an address term. Afterwards, the majority of them provide explanations such as "Estoy muy cansada y hace mucho calor" ("I am very tired and it's very hot"), "Me duele mucho la espalda" ("My back hurts"), "La verdad es que estoy muy cansado, vengo del trabajo y quiero darme un descanso" ("I am very tired, I have just come back from my work and I want to rest"). In addition, some explanations are preceded by a direct refusal, e.g. "No me apetece" ("I don't feel like doing it"), "No puedo levantarme ahora" ("I can't get up now"), "No quiero levantarme" ("I don't want to get up now") or by statements of alternative, e.g. "Si quieres, te traigo una manta" ("If you want, I'll bring you a blanket”), ¿Por qué no te pones un jersey?” (“Why don’t you take a pullover?”). Finally, ten native speakers employ requests mostly through the imperative mood, e.g. “iVe tú!” ("You go!”), “CCiérrala tú!” (“You close the window!”), “iDéjala abierta!" ("Leave it open!").

In brief, explanation strategies, address terms and pause fillers are preferably used by both groups. Nevertheless, statements of alternative occur more frequently in the native speakers' responses than in the learners' refusals. Another difference concerns the use of politeness markers, e.g. "por favor" ("please") in the requests produced by the Serbian participants, while the Spanish native speakers seem to be more direct in their requests. 


\section{Final considerations and future implications}

The present study on the speech act of refusal aimed at contrasting refusal strategies produced by Serbian learners of L2 Spanish and Spanish native speakers. The aim was to examine if they use similar strategies and what kind of differences could be found between the two groups. When producing refusals, the Serbian respondents preferably used statements of regret preceded by adverbial intensifiers (e.g. "I am so/very/really sorry"), strategies which did not frequently appear in the responses of the control group. Taking into account that the Serbian language does not either encourage the excessive use of statements of regret (preceded or followed by adverbial intensifiers), we could conclude that this feature might be transferred from English, as a first foreign language that most Serbian students learn at school.

Another difference relates to the presence of alternatives and repetitions, which were less provided by the learners and considerably more by the Spanish native speakers. Furthermore, when performing requests, the imperative construction was always preceded or followed by a politeness marker (e.g. "Please, close the window!") in the learners' data, while this was never the case in the native speakers' corpus. It is important to mention that it is rather rare to hear Serbian native speakers using the politeness marker, even in more formal situations. Thus, once again, it is possible that the Serbian participants transferred this "please" from English, in which the lack of politeness markers could be interpreted as brusque and discourteous. Finally, the Spanish native speakers provided many lexically expressed negations such as "Impossible" and elaborated their explanations in a more detailed way in the first situation (taking into account different reasons rather than just stressing the lack of time), which was not the case with the Serbian respondents.

Apart from these differences, there were also certain similarities in terms of the use and content of some refusal strategies. For instance, both the learners' and native speakers' productions were characterised by a consistent use of pause fillers and address terms - typical for colloquial Spanish. In addition, the two groups expressed the impossibility to close the window in the second situation emphasising the reason of fatigue.

Finally, for future research, it would be interesting to broaden the group of participants, to amplify the number of situations in the analysis and to contrast with other types of language learners of Spanish. Next to this, it might be interesting to contrast higher and lower proficiency learners in order to find out to which extent pragmatic competence evolves with the level of linguistic proficiency. 


\section{REFERENCES}

Abed 2011: A. Q. Abed, Pragmatic transfer in Iraqi EFL Learners' Refusals. International Journal of English Linguistics, 1(2), 166-185.

Alcón-Soler 2001: E. Alcón-Soler, Developing pragmatic competence in the academic setting: The case of suggestions in NS/NNS advising sessions. In S. Posteguillo, I. Fortanet \& J. C. Palmer (Eds.), Methodology and new technologies in language for specific purposes, Castelló: Servei de Publicacions de la Universitat Jaume I, 79-86.

Allami \& Naemi 2011: H. Allami, A. Naemi, A cross-linguistic study of refusals: An analysis of pragmatic competence development in Iranian EFL learners. Journal of Pragmatics, 43, 385-406.

Beebe, Takahashi \& Uliss-Weltz 1990: L. M. Beebe, T. Takahashi, R. UlissWeltz, Pragmatic failure in ESL refusals. In R. C. Scarcella, E. S. Anderson \& S. D. Krashen (Eds.), Developing communicative competence in a second language, New York: Newbury House Publishers, 55-94.

Blum-Kulka, House \& Kasper 1989: S. Blum-Kulka, J. House, G. Kasper, Cross-cultural Pragmatics: Requests and Apologies. Norwood, NJ: Ablex Publishing Corporation.

Brown \& Levinson 1987: P. Brown, S. C. Levinson, Politeness: Some universals in language usage. Cambridge, UK: Cambridge University Press.

Chaudron 2003: C. Chaudron, Data collection in SLA research. In C. J. Doughty \& M. H. Long (Eds.), The handbook of second language acquisition, Malden, MA: Blackwell publishing, 762-828.

Eslami 2010: Z. R. Eslami, Refusals: How to Develop Appropriate Refusal Strategies. In A. Martínez \& E. Usó-Juan (Eds.), Speech Act Performance: Theoretical, Empirical and Methodological Issues, Amsterdam: John Benjamins, 217-236.

Félix-Brasdefer 2004: J. C. Félix-Brasdefer, Interlanguage refusals: Linguistic politeness and length of residence in the target community. Language learning, 54(4), 587-653.

Fernández-Amaya 2008: L. Fernández-Amaya, Teaching Culture: Is It Possible to Avoid Pragmatic Failure? Revista Alicantina de Estudios Ingleses, 21, 11-24.

Golato 2003: A. Golato, Studying compliment responses: A comparison of DCTs and recordings of naturally occurring talk. Applied Linguistics, 24, 90-121. 
Halupka-Rešetar \& Knežević 2016: S. Halupka-Rešetar, L. Knežević, Refusals in the Production of Serbian ESP Learners. Facta universitatis-series: Linguistics and Literature, 14(2), 103-116.

Haverkate 1994: H. Haverkate, La cortesía verbal. Estudio pragmalingüistico. Madrid: Gredos.

Haverkate 1996: H. Haverkate, Modal patterns of direct and indirect discourse in Peninsular Spanish: An analysis within the framework of speech act typology. In T. Janssen \& W. Van der Wurff (Eds.), Reported Speech. Forms and functions of the verb, Amsterdam: John Benjamins, 97-119.

Hickey 2005: L. Hickey, Politeness in Spain: Thanks but no 'Thanks'. In L. Hickey \& M. Stewart (Eds.), Politeness in Europe, Clevedon: Multilingual Matters, 317-330. Housen, Kuiken \& Vedder 2012: A. Housen, F. Kuiken, I. Vedder, Dimensions of L2 Performance and Proficiency: Complexity, Accuracy and Fluency in SLA. Amsterdam/Philadelphia: John Benjamins.

Houck \& Gass 1996: N. Houck, S. M. Gass, Non-native refusal: A methodological perspective. In S. M. Gass \& J. Neu (Eds.), Speech acts across cultures, Berlin: Mouton de Gruyter, 45-64.

Kasper \& Rose 2003: G. Kasper, K. R. Rose, Pragmatic Development in a Second Language (Language learning Monograph Series v. 3). Malden, MA/ Oxford, UK: Wiley-Blackwell.

Le Pair 2005: R. Le Pair, Politeness in The Netherlands: Indirect Request. In L. Hickey \& M. Stewart (Eds.), Politeness in Europe, Clevedon: Multilingual Matters, 66-80.

Márquez Reiter 2000: R. Márquez Reiter, Linguistic Politeness in Britain and Uruguay: A contrastive study of requests and apologies. Amsterdam: John Benjamin.

Martínez-Flor \& Usó-Juan 2011: A. Martínez-Flor, E. Usó-Juan, Research Methodologies in Pragmatics. Estudios de lingüística aplicada, 11, 47-87.

Nadal López 2014: M. J. Nadal López, Análisis de errores de interlengua de español para serbiohablantes: Dificultades de uso del artículo. Red Electrónica de Didáctica del Español como Lengua Extranjera, 15.

Norris \& Ortega 2003: J. M. Norris, L. Ortega, Defining and Measuring SLA. In C.J. Doughty, M.H. Long (Eds.), Handbook of Second Language Acquisition, Malden, MA: Blackwell, 717-761.

Robinson 1992: M. S. Robinson, Introspective methodology in interlanguage pragmatics research. In G. Kasper (Ed.), Pragmatics of Japanese as Native and Target Language, Honolulu: University of Hawaii Press, 27-82. 
Sasaki 1998: M. Sasaki, Investigating EFL students' production of speech acts: A comparison of production questionnaires and role plays. Journal of Pragmatics, 30(4), 457-484.

Savić 2014: M. Savić, Politeness through the Prism of Requests, Apologies and Refusals: A case of Advanced Serbian EFL Learners. Cambridge: Cambridge Scholars Publishing.

Siebold \& Busch 2015: K. Siebold, H. Busch, (No) Need for Clarity - Facework in Spanish and German Refusals. Journal of Pragmatics, 75, 53-68.

Taguchi 2017: N. Taguchi, Interlanguage Pragmatics. In A. Barron et al. (Eds.), The Routledge Handbook of Pragmatics, Oxford/New York: Routledge, 153-167.

Taguchi \& Roever 2017: N. Taguchi, C. Roever, Second Language Pragmatics. Oxford: Oxford University Press.

Takahashi \& Beebe 1987: T. Takahashi, L. M. Beebe, The development of pragmatic competence by Japanese learners of English. JALT Journal, 8, 131-55.

Tanck 2002: S. Tanck, Speech Act Sets of Refusal and Complaint: A Comparison of Native and Non-Native English Speakers' Production. TESL 523 Second Language Acquisition, 1-22. Washington, DC: American University. Tello Rueda 2006: Y. Tello Rueda, Developing Pragmatic Competence in a Foreign Language. Colombian Applied Linguistics Journal, 8, 170-182. 


\section{Jovana Stanojević, An Vande Casteele}

\section{COMPETENCIA PRAGMÁTICA DE APRENDICES SERBIOS DE ESPAÑOL}

\section{Resumen}

El objetivo del presente estudio es examinar las estrategias pragmáticas empleadas en los actos de habla de rechazo por aprendices serbios de español. Como método de investigación, utilizamos un cuestionario DCT (Discourse Completion Test). Concretamente, nos servimos de dos diálogos en que los participantes tienen que rechazar lo que se les expone. Contamos con dos grupos en total: un grupo de 20 aprendices serbios y un grupo de control de 20 españoles nativos. Ahora bien, con respecto a las diferencias entre estos dos grupos, el análisis muestra que los aprendices serbios tienden a usar las estrategias de disculpa seguidas de intensificadores adverbiales ("Lo siento mucho"), un elemento escasamente utilizado por el grupo de control. Asimismo, las peticiones de los aprendices suelen ser seguidas del marcador de cortesía ("por favor"), un elemento no encontrado en las respuestas de los españoles nativos. Como estos dos rasgos tampoco suelen ser frecuentes en serbio, los resultados nos permiten concluir que los aprendices serbios suelen transferirlos del inglés, como primera lengua extranjera que la mayoría de los serbios aprende en la escuela. A eso viene a añadirse que los españoles ofrecen explicaciones más detalladas y se sirven de negaciones léxicas ("Imposible"), lo que no es el caso con los aprendices. Por lo que atañe a las semejanzas, cabe destacar que los dos grupos emplean muletillas ("pues, es que") y vocativos informales ("tío, hombre"), dos rasgos muy frecuentes en la cultura española.

Palabras clave: competencia pragmática, actos de habla, rechazos, español como lengua extranjera. 


\section{Jovana Stanojević, An Vande Kastel}

\section{PRAGMATIČKA KOMPETENCIJA SRPSKIH STUDENATA ŠPANSKOG JEZIKA}

\section{Rezime}

Cilj ove studije je da ispita pragmatičke strategije koje srpski studenti španskog jezika koriste u govornom činu odbijanja. Kao metod istraživanja, služimo se upitnikom DCT (Discourse Completion Test). Tačnije, predstavljamo dva dijaloga u kojima učesnici moraju da odbiju sve što im se ponudi. Računamo na dve grupe: jednu grupu od 20 srpskih učenika španskog jezika i jednu kontrolnu grupu od 20 španskih izvornih govornika. Što se tiče razlika između ove dve grupe, analiza pokazuje da srpski učenici imaju tendenciju da koriste strategije izvinjenja praćene adverbijalnim intenzifikatorima ("Lo siento mucho"), elemenat koji je retko korišćen od strane kontrolne grupe. Isto tako, srpski učenici španskog jezika često dodaju marker učtivosti ("por favor") nakon molbi, što nije slučaj sa kontrolnom grupom. Kako ove dve osobine nisu česte ni u srpskom jeziku, rezultati nas navode na zaključak da ih srpski učenici prenose sa engleskog, kao prvog stranog jezika koji većina Srba uči u školi. Takođe, kontrolna grupa koristi detaljnija objašnjenja i dosta leksičkih negacija ("Imposible"), što nije slučaj sa srpskim učenicima španskog. Što se tiče sličnosti, trebalo bi napomenuti da obe grupe primenjuju dosta neformalnih vokativa ("tio, hombre") i poštapalica ("pues, es que"), dve formule inače česte u španskoj kulturi.

Ključne reči: pragmatička kompetencija, govorni činovi, odbijanje, španski kao strani jezik. 